\title{
Pengaruh Tayangan Drama Korea True Beauty Terhadap Minat Beli Produk K-Beauty
}

\author{
Riahta Octaviani $^{1 *}$, Zainal Abidin ${ }^{2}$, Flori Mardiana Lubis ${ }^{3}$ \\ ${ }^{1,2,3}$ Universitas Singaperbangsa Karawang, Indonesia \\ *email : riahtaocta@gmail.com
}

\begin{abstract}
This research is motivated by the writer interest in Korean drama shows. So finally doing research to see the impact on one of the communities in Cikarang, namely the TnT Label Community, which is basically a K-pop dance cover community. So the purpose of this study is to find out whether there is an effect of the drama True Beauty on buying interest in K-Beauty products in the TnT Label dance cover community. This research was conducted with a quantitative method using an explanatory survey. The purpose of this study was to find out how the influence of Korean drama True Beauty on buying interest in K-Beauty products. The theory used in this research is IMC (Integrated Marketing Communication) Theory. The population in this study were all members of the TnT Label Community in Cikarang. Data collection was obtained through the distribution of questionnaires and literature study.
\end{abstract}

Keywords: korean drama, k-beauty, buying interest, community, integrated marketing communication

\begin{abstract}
Abstrak: Penelitian ini dilatarbelakangi oleh ketertarikan penulis terhadap tayangan drama Korea. Sehingga akhirnya melakukan penelitian untuk melihat pengaruh yang ditimbulkan pada salah satu komunitas yang berada di Cikarang yaitu Komunitas TnT Label yang dasarnya adalah komunitas dance cover K-pop. Maka tujuan penelitian ini untuk mengetahui adakah pengaruh tayangan drama True Beauty terhadap minat beli produk K-Beauty pada komunitas dance cover TnT Label. Penelitian ini dilakukan dengan metode kuantitatif yang menggunakan survey eksplanatori. Tujuan dari penelitian ini adalah untuk mengetahui bagaimana pengaruh tayangan drama korea True Beauty terhadap minat beli produk KBeauty. Teori yang digunakan dalam penelitian ini adalah Teori IMC (Integrated Marketing Communication). Populasi dalam penelitian ini adalah seluruh anggota dari Komunitas TnT Label di Cikarang. Pengumpulan data didapat melalui penyebaran kuesioner dan studi kepustakaan.
\end{abstract}

Kata Kunci: drama Korea, k-beauty, minat beli, komunitas, integrated marketing communication

Copyright (c) 2021 The Authors. This is an open access article under the CC BY-SA 4.0 license (https://creativecommons.org/licenses/by-sa/4.0/)

\section{PENDAHULUAN}

Pada tahun 2002, berita tentang budaya Korea mulai meningkat di negaranegara Asia. Dalam beberapa tahun terakhir, perkembangan Hallyu sangat pesat dan signifikan. Fenomena Hallyu ini dengan cepat menyebar ke kawasan Asia termasuk Asia Tenggara, sehingga Indonesia merupakan salah satu negara yang terkena dampak fenomena Hallyu. Hallyu atau Hallyu adalah istilah untuk budaya pop Korea 
yang tersebar di berbagai negara/wilayah dunia, termasuk Indonesia (Idola Perdini Putri, 2019). Budaya Korea sangat menarik bagi banyak orang, karena banyak orang dari negara lain menganggap perpaduan budaya tradisional Korea dan budaya modern adalah unik di negara ini. Korean Pop Culture atau K-Pop adalah budaya musik dari Korea yang menarik simpati anak muda dari seluruh dunia. Selain itu, meningkatnya konsumsi film dan drama televisi Korea menyebabkan remaja Indonesia memuja para aktor dan aktris yang memerankannya. Dengan kemudahan akses terhadap konten budaya Korea Selatan, masyarakat Indonesia seolah terbuka jalannya untuk lebih mengenal budaya Korea. sejak dahulu memang banyak Brand Korea yang menggunakan K-drama sebagai media promosi dari suatu produk. Seperti halnya KBeauty, seiring dengan menyebarnya industri hiburan Korea Selatan, produk K-beauty seperti kosmetik dan gaya berpakaian juga ikut dikenal oleh para remaja Indonesia.

Lembaga riset pasar Mitel menyebutkan pertumbuhan kosmetik dan perawatan kulit Korea mencapai 5,8 persen dari tahun ke tahun sejak 2013.Di Asia Tenggara, Korea Selatan menaruh minat besar terhadap Indonesia sebagai pangsa pasar di Asia. Selain negara berpenduduk terbesar di Asia Tenggara, Indonesia adalah salah satu kantong fanbase Korean Wave terbesar di dunia. Badan Pusat Statistik mencatat impor kosmetik dan skin care Korea mencapai 5,9 juta dolar AS pada tahun 2016. Animo ini makin terlihat tiap ada gelaran misi perdagangan brand Korea. Menurut KOTRA (Korea Trade-Invesment Promotion Agency), dalam sebulan bisa ada sekitar 60 perusahaan kosmetik Korea yang berminat ke pasar Indonesia (Putri, 2017). Oleh karena itu, hal tersebut berpengaruh kepada minat beli masyarakat Indonesia terhadap produk-produk kecantikan Korea Selatan. Berdasarkan uraian yang telah dipaparkan peneliti tertarik untuk mengetahui Apakah ada Pengaruh yang ditimbulkan secara signifikan dari Tayangan Drama Korea True beauty terhadap Minat beli produk Kbeauty. Drama Korea True beauty merupakan salah satu drama Korea yang diadaptasi dari cerita webtoon Korea karya Yaongyi dengan judul yang serupa atau di Indonesia lebih dikenal dengan judul 'The Secret of Angel'. mengkisahkan seorang gadis SMA bernama Lim Joo Kyung (diperankan oleh Moon Ga Yeong) yang memiliki masalah kompleks terhadap penampilan wajahnya, sehingga harus terpaksa menerima penolakan dari lingkungan sosial sekitarnya. Adapun Lee Soo Ho (diperankan oleh Cha Eun Woo), dan Han Seo Jun (diperankan oleh Hwang In Yeop) merupakan 2 siswa SMA rupawan yang hadir di dalam kehidupan Im Joo Gyeong ketika pindah ke sekolahnya yang baru. Kemampuan merias wajah yang handal, membuat Lim Joo 
Kyung berhasil untuk dapat benar-benar memulai langkah hidupnya yang baru sebagai seorang siswi SMA di lingkungan sekolahnya, namun kekahawatiran untuk hidup tanpa riasan wajah menjadi tantangan lain yang harus dihadapi oleh Lim Joo Kyung selama menjalani kehidupannya di sekolah yang baru. Gejolak kisah romantis dengan selingan adegan komedi dalam drama ini disisi lain juga mengandung begitu banyak pelajaran berharga yang dapat diperoleh dan dipelajari dalam kehidupan sehari-hari.

Penelitian ini menggunakan teori dari Marketing Communication yaitu IMC (Integrated Marketing Communication) Menurut (Terence, 2014), Integrated Marketing Communication atau IMC merupakan proses komunikasi yang memerlukan perencanaan, penciptaan, integrasi dan implementasi dari berbagai bentuk elemen yang ada pada marketing communication seperti iklan, promosi penjualan, publisitas, acaraacara dan yang lainnya yang disampaikan dari waktu ke waktu kepada pelanggan dan calon pelanggan. Integrated Marketing Communication ini merupakan salah satu bagian dari manajemen pemasaran yang terdiri dari advertising ,public relations, sponsorship, personal selling, direct marketing, serta sales promotion yang saling mendukung satu sama lain. Adanya Integrated Marketing Communication menjadikan sebuah perusahaan atau industri dapat menyasar pangsa pasar dengan efektif dan tepatkerangka berpikir Integrated Marketing Communication, tiap elemen bauran pemasaran dapat dikombinasikan untuk mencapai tujuan utamanya, yaitu mempengaruhi atau secara langsung menghasilkan perilaku yang diinginkan dari konsumen. IMC memanfaatkan kontak antara brand dengan konsumen sebagai saluran potensial untuk menyampaikan pesan yang relevan bagi konsumen. Perlu dipastikan bahwa seluruh pesan komunikasi brand tersebut disampaikan secara konsisten sekalipun menggunakan berbagai metode dalam penyampaiannya. Sehingga penelitian ini bertujuan untuk mengetahui pengaruh yang ditimbulkan oleh serial drama Korea "True Beauty" terhadap Minat beli produk K-Beauty pada Komunitas dance cover Korea yaitu Komunitas TnT Label di Cikarang.

Menurut Mujiono dalam (Suradi, 2012), Minat beli adalah aktivitas psikis yang timbul karena adanya perasaan (afekti) dan pikiran (kognitif) terhadap suatu barang atau jasa yang diinginkan. Menurut Engel dalam (Julianti, 2014) minat beli sebagai kekuatan pendorong atau motif yang instristik yang mampu mendorong seseorang untuk menaruh perhatian secara spontan, wajar, mudah, tanpa paksaan dan selektif pada satu produk untuk kemudian mengambil keputusan membeli. Hal ini karena adanya 
kesesuaian dengan kepentingan individu yang memberi kesenangan, kepuasan pada dirinya. Jadi sangat jelas bahwa minat beli diartikan sebagai suatu sikap menyukai yang ditujukan dengan kecenderungan untuk selalu membeli yang disesuaikan dengan kesenangan dan kepentingannya. Sedangkan Indikator Minat beli Menurut Ferdinand dalam (Hariani, 2013) minat beli dapat diidentifikasi melalui beberapa indikator yaitu:

1) Minat transaksional, yaitu kecenderungan seseorang untuk membeli produk. Minat refrensial, yaitu kecenderungan seseorang untuk merefrensikan produk kepada orang lain.

2) Minat prefrensial, yaitu yang menggambarkan perilaku seseorang yang memiliki prefrensi utamam pada produk tersebut. Prefrensi ini hanya dapat diganti jika terjadi sesuatu dengan produk prefrensinya.

3) Minat eksploratif, yaitu minat ini menggambarkan perilaku seseorang yang selalu mencari informasi mengenai produk yang diminatinya dan mencari informasi untuk mendukung sifat-sifat positif dari produk tersebut.

Dengan tujuan dari penelitian ini yaitu:

1. Untuk mengetahui pengaruh intensitas menonton Drama Korea "True Beauty" terhadap minat beli produk K-Beauty.

2. Untuk mengetahui pengaruh isi pesan saat menonton drama terhadap minat beli produk K-Beauty

3. Untuk mengetahui daya tarik yang ada saat menonton Drama Korea "True Beauty" terhadap minat beli produk K-Beauty.

Penelitian ini diharapkan dapat menjadi rujukan dan bahan kajian/teori bagi penelitian di bidang ilmu komunikasi mengenai pengaruh suatu tayangan drama korea terhadap minat beli suatu produk.

\section{METODE PENELITIAN}

Dalam penelitian metode yang digunakan adalah metode kuantitatif, menurut (Sugiyono, 2012) Metode kuantitatif merupakan metode yang didasarkan pada filosofi positivisme disebut juga dengan metode positivis, karena penggunaannya memberikan bukti atau konfirmasi maka kuantifikasi disebut juga dengan metode konfirmatori. Untuk jenis, penelitian ini masuk dalam penelitian eksplanatori yang bertujuan untuk menjelaskan mengapa peristiwa atau gejala tersebut terjadi. Hasil akhir dari penelitian ini adalah gambaran hubungan sebab akibat (Priyono, 2016).

\section{Populasi dan Sampel}


Menurut (Arikunto, 2006) "populasi adalah keseluruhan objek penelitian". Penelitian hanya dapat dilakukan bagi populasi terhingga dan subyeknya tidak terlalu banyak. Populasi dalam penelitian ini adalah Anggota komunitas Dance Cover Cikarang TNT Label, yang berjumlah 60 orang Adapun Sampel adalah sebagian atau wakil dari populasi yang akan diteliti. Pengambilan sampel untuk penelitian menurut (Arikunto, 2010), jika subjeknya kurang dari 100 orang sebaiknya diambil semuanya, jika subjeknya besar atau lebih dari 100 orang dapat diambil 10-15\% atau 20-25\% atau lebih.

\section{Teknik Analisis Data}

\section{Uji Normalitas}

Dalam penelitian ini, peneliti menggunakan uji Kolmogorov-Smirnov menggunakan bantuan SPSS 25.0 for windows 10 (32 bit). yang digunakan sebagai teknik dan kemudian menguji data yang dikumpulkan untuk menentukan apakah data tersebut berasal dari populasi yang berdistribusi normal. Uji Kolmogorov Smirnov dianggap sebagai uji normalitas umum karena penerapannya sederhana dan tidak menimbulkan perbedaan persepsi (Ghozali, 2007).

\section{Uji Regresi Sederhana}

Menurut (Sugiyono, 2013) mendefinisikan bahwa analisis regresi sederhana adalah pengujian terhadap data yang mana terdiri dari variabel, yaitu satu variabel independen dan satu variabel dependen, dimana variabel tersebut bersifat kausal (berpengaruh). Uji regresi linear sederhana dmiaksudkan untuk mengukur pengaruh antara variabel X (Tayangan Drama Korea True Beauty) dengan variabel Y (Minat Beli produk K-Beauty)

\section{Uji Parsial T}

(Ghozali, 2012) menjelaskan bahwa uji t digunakan untuk mengukur tingkat pengaruh parsial variabel independen terhadap variabel dependent. Uji T dilakukan untuk mengetahui apakah secara individu (parsial) variabel independent mempengaruhi variabel dependent secara signifikan atau tidak dengan menguji berpengaruh atau tidaknya hubungan variabel-variabel independen Intensitas (X1), Isi Pesan (X2), Daya Tarik (X3), dengan variabel dependen Minat beli produk K-beauty (Y).

\section{Koefisien Determinasi}

Koefisien determinasi merupakan bagian dari analisis regresi linier berganda yang mengukur kemampuan variabel bebas dalam menjelaskan variabel terikat. nilai koefisien determinasi mewakili proporsi variabel dependen yang dapat dijelaskan oleh 
variabel praduga. Rentang nilai koefisien determinasi adalah antara 0 dan 1, jika nilai koefisien determinasi mendekati 1 maka variabel bebas mempunyai pengaruh terhadap variabel terikat, dan semakin kuat pengaruhnya. Sebaliknya jika koefisien determinasi mendekati 0, pengaruh variabel bebas terhadap variabel terikat semakin lemah (Nawari, 2010). Hal ini dilakukan untuk mengetahui besarnya pengaruh variabel bebas X1 (kekuatan), X2 (isi pesan) dan X3 (daya tarik) terhadap minat beli variabel terikat produk K-Beauty.

\section{HASIL DAN PEMBAHASAN}

Dalam penelitian ini, dipilih sebanyak 60 anggota dari komunitas TnT label sebagai responden, dengan umur 18-25 tahun, dengan pekerjaan atau kesibukan yang dimiliki dari yang sedang menempuh pendidikan strata 1 di Universitas maupun responden yang sudah bekerja sebagai karyawan/wiraswasta. Berdasarkan penelitian yang telah dilakukan, peneliti akan menguraikan hal-hal yang berkaitan dengan data yang telah berhasil dikumpulkan dan dibahas berdasarkan hasil penelitian diantaranya: Uji normalitas, Uji regresi linear sederhana, Uji parsial (T) dan Uji koefisien determiasi $\left(\mathrm{R}^{2}\right)$.

Berikut ini merupakan hasil output pengujian normalitas dan menggunakan Test of Normality Solmogrov-Smirnov dalam program SPSS 25 :

Table 1 Hasil Uji Normalitas

One-Sample Kolmogorov-Smirnov Test

\begin{tabular}{lll} 
& & \multicolumn{1}{c}{$\begin{array}{l}\text { Unstandardiz } \\
\text { ed Residual }\end{array}$} \\
\hline $\mathbf{N}$ & & 60 \\
\hline Normal Parameters $^{\mathbf{a}, \mathbf{b}}$ & Mean & .0000000 \\
\cline { 2 - 3 } & $\begin{array}{l}\text { Std. } \\
\text { Deviation }\end{array}$ & 9.07408419 \\
\hline $\begin{array}{l}\text { Most Extreme } \\
\text { Differences }\end{array}$ & \begin{tabular}{l} 
Absolute \\
\cline { 2 - 3 }
\end{tabular} & .087 \\
\cline { 2 - 3 } & Positive & .058 \\
\hline Nest Statistic & Negative & -.087 \\
\hline Asymp. Sig. (2-tailed) & .087 \\
\hline a. Test distribution is Normal. & $.200^{\text {c,d }}$ \\
\hline b. Calculated from data. & \\
\hline
\end{tabular}




\section{c. Lilliefors Significance Correction.}

d. This is a lower bound of the true significance.

Dari tabel diatas, hasil output SPSS dapat dilihat bahwa hasil Uji Normalitas menyatakan nilai Asymp. Sig (2-tailed) sebesar 0,200>0,05. Berdasarkan hasil tersebut dapat dinyatakan data yang digunakan dalam penelitian ini telah berdistribusi normal.

\section{Uji Regresi Linear Sederhana}

Uji regresi linear sederhana diaksudkan untuk mengukur pengaruh antara variabel X (Tayangan Drama Korea True Beauty) dengan variabel Y (Minat Beli produk K-Beauty). Berikut ini merupakan hasil output menggunakan program SPSS 25:

\section{Table 2 Hasil Uji Regresi Linear Sederhana}

a. Dependent Variable: Minat Beli Produk K-Beauty

\section{Coefficients $^{\mathrm{a}}$}

\begin{tabular}{|c|c|c|c|c|c|}
\hline \multirow[b]{2}{*}{ Model } & \multicolumn{2}{|c|}{$\begin{array}{l}\text { Unstandardized } \\
\text { Coefficients }\end{array}$} & \multirow{2}{*}{$\begin{array}{l}\text { Standardized } \\
\text { Coefficients } \\
\text { Beta } \\
\end{array}$} & \multirow{2}{*}{ t } & \multirow[b]{2}{*}{ Sig. } \\
\hline & $\mathrm{B}$ & Std. Error & & & \\
\hline 1 (Constant) & -8.900 & 9.943 & & -.895 & .374 \\
\hline $\begin{array}{l}\text { Tayangan Drama } \\
\text { Korea True Beauty }\end{array}$ & .917 & .231 & .462 & 3.966 & .000 \\
\hline
\end{tabular}

a. Dependent Variable: Minat Beli produk K-Beauty

Berdasarkan hasil tabel diatas maka didapatkan uji regresi sederhana dari table Coefficients diperoleh nilai signifikansi sebesar $0,000<0,05$, sehingga dapat disimpulkan bahwa variable Tayangan Drama Korea True Beauty (X) berpengaruh terhadap variabel Minat Beli Produk K-Beauty (Y). Angka koefisien regresi mempunyai nilai sebesar 0,917 . Angka ini menandakan bahwa setiap penambahan $0 \%$ tingkat pengaruh tayangan drama Korea True Beauty (X) maka nilai Minat Beli Produk 
K-Beauty (Y) akan meningkat sebesar 0,917. Karena nilai koefisien regresi bernilai positif, maka dengan demikian dapat dikatakan bahwa tayangan drama True Beauty (X) berpengaruh positif terhadap Minat Beli Produk K-Beauty (Y).

\section{Uji Parsial (T)}

Uji T dilakukan untuk mengetahui apakah secara individu (parsial) variabel independent mempengaruhi variabel dependent secara signifikan atau tidak. Berikut ini merupakan hasil output menggunakan program SPSS 25:

Table 3 Hasil Uji Parsial T

\section{Coefficients $^{\mathrm{a}}$}

\begin{tabular}{|c|c|c|c|c|c|c|}
\hline \multirow[b]{2}{*}{ Model } & & \multicolumn{2}{|c|}{ Unstandardized Coefficients } & \multirow{2}{*}{$\begin{array}{l}\text { Standardized } \\
\text { Coefficients } \\
\text { Beta }\end{array}$} & \multirow[b]{2}{*}{$\mathrm{t}$} & \multirow[b]{2}{*}{ Sig. } \\
\hline & & $\mathrm{B}$ & Std. Error & & & \\
\hline \multirow[t]{4}{*}{1} & (Constant) & -5.491 & 9.441 & & -.582 & .563 \\
\hline & Intensitas & .960 & .692 & .165 & 1.387 & .171 \\
\hline & Isi Pesan & -1.460 & .771 & -.273 & -1.893 & .063 \\
\hline & Daya Tarik & 2.521 & .501 & .679 & 5.032 & .000 \\
\hline
\end{tabular}

a. Dependent Variable: Minat Beli

Dasar pengambilan keputusan :

Ho diterima dan Ha ditolak jika nilai t hitung < t tabel atau jika Sig $>0,05$

Ho ditolak dan Ha Diterima jika nilai thitung > t tabel atau jika Sig < 0,05

Dengan tingkat kepercayaan yang digunakkan sebesar $95 \%$. Maka nilai $\alpha=0,05$. Sebelumnya t tabel perlu dihitung terlebih dahulu menggunakan rumus $(\mathrm{t}$ tabel $=\alpha / 2$ : n-k-1).

$(\mathrm{t}$ tabel $=\alpha / 2: \mathrm{n}-\mathrm{k}-1)$

$(\mathrm{t}$ tabel $=0,05 / 2: \mathrm{n}-\mathrm{k}-1)$

$(\mathrm{t}$ tabel $=0,05 / 2: 60-3-1)$

$(\mathrm{t}$ tabel $=0,025: 56)$

$\mathrm{t}$ tabel=0,025:56 yang kemudian diperoleh pada distribusi nilai $\mathrm{t}$ tabel sebesar 2,003.

Berdasarkan output tabel diatas, pada variabel X1 (Intensitas) didapatkan $\mathrm{t}$ hitung $=1,387$ dan Sig = 0,171 > 0,05. Maka Ho diterima dan Ha ditolak yang berarti variabel Intensitas tidak berpengaruh signifikan terhadap minat beli. Pada Variabel 2 (Isi Pesan) didapatkan nilai t hitung $-1,893$ dan Sig $=0,063>0,05$. Maka Maka Ho diterima dan Ha ditolak yang berarti variabel Isi Pesan tidak berpengaruh signifikan terhadap minat beli. Dan terakhir X3 ( Daya Tarik) diapatkan t hitung = 5,032 dan Sig 
$=0,000<0,05$. Maka Ha diterima dan Ho ditolak yang berarti variabel Daya Tarik berpengaruh signifikan terhadap minat beli.

Dari hasil perhitungan tiap variabel dapat disimpulkan bahwa variabel X1 (Intensitas)dan variabel X2 (Isi Pesan) tidak berpengaruh signifikan terhadap minat beli. Hal ini menunjukan bahwa intensitas atau banyaknya waktu yang digunakan untuk menonton tayanagan drama korea True beauty dan juga isi pesan yang disampaikan lewat drama korea ini tidak memiliki pengaruh yang cukup membuat reponden memiliki minat beli terhadap produk K-Beauty, karena mayoritas penonton menjadikan drama serial Korea sebagai tontonan dikala senggang dan menjadi sumber hiburan bagi mereka, dimana masyarakat menonton hanya untuk menyenangkan hatinya. juga menghindarkan diri dari tekanan dan ketegangan dari aktivitas sehari hari. Selain itu, cerita yang ditampilkan dalam drama sesuai dengan budaya masyarakat pada umumnya, konsep mengenai cinta sejati, pengorbanan, dan konsep kehidupan lain yang tergambar dalam drama Korea tidak bertentangan terlalu jauh dengan konsep kehidupan yang ada pada masyarakat Asia pada umumnya (Frulyndese, 2016)

Namun lain hal nya dengan variabel X3 (Daya tarik) dilihat memiliki pengaruh signifikan terhadap minat beli produk K-Beauty, hal ini menunjukan bahwa drama True Beauty ini memiliki daya tarik yang berpengaruh positif pada mayoritas responden. Beradasarkan hasil yang didapatkan pada pertanyaan kuisioner yang disebarkan oleh peneliti, mayoritas menjawab sangat setuju untuk pertanyaan berkaitan denagn pemain dalam drama korea True beauty ini memiliki perawakan yang menarik sehingga menjadi daya tarik. Sederet Aktor dan Aktris yang ada dalam drama True Beauty ini antara lain Cha Eunwoo yang merupakan anggota idol grup ASTRO memiliki perawakan tampan, Moon Gayoung yang merupakan aktris cantik yang banyak membintangi judul drama terkenal, dan juga Hwang Inyeop seorang aktor tampan yang menarik perhatian para remaja dalam setiap judul drama yang dibintanginya. Aktor dan Aktris yang merupakan pemain drama True Beauty ini termasuk dalam Aktor dan aktris yang banyak digandrungi para penggemar drama Korea baik dalam kemampuan aktingnya maupun dari segi wajah dan juga penampilan yang menarik, maka dari itu hal ini sejalan dengan tanggapan para responden yang menjawab sangat setuju bahwa para pemain drama True Beauty memiliki perawakan yang tampan dan cantik juga berpenampilan menarik. 


\section{Uji Koefisien Determinasi $\left(R^{2}\right)$}

Uji Regresi Linear sederhana dimaksudkan untuk mengukur pengaruh antara Variabel X (Tayangan Drama Korea True beauty) dengan Variabel Y (minat beli produk K-Beauty). Berikut ini merupakan hasil output menggunakan SPSS 25 :

Table 4 Hasil Uji Koefisien Determinasi

\begin{tabular}{|c|c|c|c|c|c|}
\hline \multicolumn{6}{|c|}{ Model Summary } \\
\hline Model & 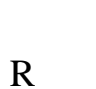 & R Square & $\begin{array}{l}\text { Adjusted } \\
\text { Square }\end{array}$ & $\mathrm{R}$ & $\begin{array}{l}\text { Std. Error of } \\
\text { the Estimate }\end{array}$ \\
\hline 1 & $.462^{\mathrm{a}}$ & .213 & .200 & & 9.152 \\
\hline
\end{tabular}

a. Predictors: (Constant), Tayangan Drama Korea True Beauty

b. Dependent Variable: Minat Beli produk K-Beauty

Dari tabel diatas diperolah nilai Adjusted $=0,200=20,0 \%$. Ini berarti besarnya pengaruh intensitas, isi pesan, dan daya tarik berpengaruh positif terhadap Minat Beli produk K-Beauty sebesar 20,0\% dan sisanya dipengaruhi oleh variabel lain yang tidak masuk dalam penelitian ini.

\section{SIMPULAN}

Berdasarkan pemaparan dari hasil penelitian mengenai "Pengaruh Tayangan Drama Korea True Beauty terhadap Minat beli produk K-Beauty” yang peneliti kaji dapat disimpulkan bahwa Variabel X1 (Intensitas) dan Varibel 2 (Isi Pesan) didapatkan tidak berpengaruh signifikan terhadap minat beli. Sedangkan untuk variabel X3 (Daya Tarik) didapatkan berpengaruh signifikan terhadap minat beli. Penelitian ini dilakukan dengan jumlah responden sebanyak 60orang. Hasilnya terlihat bahwa tidak dapat diharapkan setiap individu mendapat pengaruh yang signifikan dari setiap variabel sehingga mempengaruhi minat beli produk K-beauty.

\section{SARAN}

Adapun saran-saran yang penulis berikan setelah meneliti masalah dalam penelitian ini antara lain:

1. Peneliti berharap penelitian ini dapat menjadi masukan informasi bagi para pecinta K-beauty untuk dapat mengambil sisi positif dari setiap tayangan drama ataupun film Korea dan menjadikannya sebagai bahan pembelajaran.

2. Peneliti ini diharapkan dapat menjadi landasan dan menambah wawasan masyarakat tentang efek dari fenomena merebaknya kegemaran masyarakat terhadap Korea.salah satunya kegemaran masyarakat terhadap drama Korea agar lebih berguna bagi masyarakat luas. 


\section{DAFTAR RUJUKAN}

Arikunto, S. (2006) Prosedur Penelitian Suatu Pendekatan Praktik. Jakarta: Rineka Cipta.

Arikunto, S. (2010) Prosedur Penelitian Suatu Pendekatan Praktik. Jakarta: Rineka Cipta.

Frulyndese, S. (2016) 'Fenomena Konsumsi Budaya Korea pada Anak Muda di Kota Manado', Jurnal Holistik, 18.

Ghozali, I. (2007) Aplikasi Analisis Multivariate dengan Program SPSS. Semarang: Universitas Diponegoro.

Ghozali, I. (2012) Aplikasi Analisis Multivariate dengan Program IBM SPSS. Yogyakarta: Universitas Diponegoro.

Hariani (2013) 'Analisis Pengaruh Bauran Pemasaran terhadap Minat Beli Konsumen Menggunakan Gas LPG'.

Idola Perdini Putri, F. D. P. L. dan R. N. (2019) 'K-Drama dan Penyebaran Korean Wave di Indonesia', Universitas Padjajaran Bandung.

Julianti, L. (2014) 'Pengaruh Suasana Toko (Store Atmosphere) terhadap Minat Beli Konsumen pada Toserba Nusa Permai di Kecamatan Nusa Padina', Jurnal Pendidikan Ekonomi, 4.

Nawari (2010) Analisis Regresi dengan MS Excel 2007 dan SPSS 17. Jakarta: PT Elex Media Komputindo.

Priyono (2016) Metode Penelitian Kuantitatif. Sidoarjo: Zifatama Publishing.

Putri (2017) Indonesia, Target Pasar Seksi K-Beauty di Asia, Tirto.id. Available at: https://tirto.id/indonesia-target-pasar-seksi-k-beauty-di-asiacyRj\%0Ahttps://www.uc.ac.id/library/makna-kehidupan-dalam-cerita-drama-truebeauty\%0A.

Sugiyono (2012) Metode Penelitian Kuantitatif, Kualitatif dan Kombinasi (Mixed Methods). Bandung: ALFABETA.

Sugiyono (2013) Metodologi Penelitian Kuantitatif, Kualitatif dan R\&D. Bandung: ALFABETA.

Suradi (2012) 'Faktor-Faktor yang Mempengaruhi Minat Beli Konsumen terhadap Produk Tepung Sagu (Studi Kasus pada Masyarakat Desa Selat Akar Merbau)', Jurnal Administrasi Niaga.

Terence, S. (2014) Komunikasi Pemasaran Terpadu dalam Periklanan dan Promosi. Jakarta: Salemba Empat. 